CAROLINA PURCELL GOES

\title{
Regulação pré- e pós-transcricional do gene Scratch2 durante a neurogênese no tubo neural posterior
}

Tese apresentada ao Programa de Pós-Graduação em Biologia de Sistemas do Instituto de Ciências Biomédicas da Universidade de São Paulo, para obtenção do Título de Doutora em Ciências. 


\section{RESUMO}

Goes, CP. Regulação pré- e pós-transcricional do gene Scratch2 durante a neurogênese no tubo neural posterior. [tese (Doutorado em Biologia de Sistemas)] - Instituto de Ciências Biomédicas, Universidade de São Paulo, São Paulo; 2019.

Scratch2 é um fator de transcrição expresso em células recém-egressas do ciclo celular e tem um papel conservado na sobrevivência, diferenciação e migração celular. Scrt2 é expresso em uma população bem restrita de células localizadas na camada interna da zona intermediária do tubo neural em embriões de galinha, e seu padrão de expressão se mantem conservado em vertebrados. Os mecanismos que controlam a sua expressão ainda são desconhecidos e podem contribuir no entendimento sobre regulação gênica durante a diferenciação neural. Aqui, investigamos os mecanismos regulatórios pré- (enhancers e fatores de transcrição) e pós-transcricionais (miRNAs) envolvidos na expressão de cScrt2. Realizamos uma análise in silico e identificamos 1) um potencial elemento-cis conservado (E1), presente tanto em galinha quanto em camundongo, que pode estar envolvido na expressão de Scrt2; 2) Ascl1, Brn2 e Sox2 como fatores de transcrição candidatos a controladores à montante de Scrt2 na cascata gênica, e 3) sítios de ligação para miR-125b, -200b, -429, -211 e -204 na região 3'UTR de cScrt2. Testamos a função biológica da região regulatória candidata E1 e da região 3'UTR de Scrt2 pela eletroporação no tubo neural embrionário de galinha. A modulação de transcrição modulada por fatores de transcrição via E1 foi testada em ensaio luciferase em células HEK293T. Além disso, realizamos Chromosome Conformation Capture (3C) para verificar interações entre E1 e a região promotora de cScrt2, e utilizamos a metodologia CRISPR/Cas9 para editar E1 e sítios-alvo de miRNAs na 3'UTR de cScrt2. Nossos resultados indicam que E1 é m enhancer neural, que dirige a expressão de Scrt2 possivelmente no domínio equatorial do tubo neural. A superexpressão dos fatores de transcrição selecionados, aumentou a expressão de $c S c r t 2$ na região dorsal do tubo neural e reduziu o número de subpopulações de células neurais diferenciadas. Além disso, a edição de sítios de miRNA mediada por CRISPR, aumentou a expressão de Scrt2, sugerindo um possível papel de miR-125b e -200b na regulação pós-transcricional de cScrt2. Por fim, propomos que o domino de expressão de cScrt2 seja gerado pela conjunção dos mecanismos de regulação pré- e póstranscricionais. Neste cenário, E1 modula a transcrição de cSrt2 mediada pelos fatores de transcrição Ascl1 e Brn2. Após a transcrição, os níveis de cScrt2 seriam então delimitados pela ação de miR-125b e -200b na sua 3'UTR.

Palavras-chave: Neurogênese. Scratch. Regulação gênica. Elementos-cis. miRNA. 


\begin{abstract}
Goes, CP. Pre- and Post-transcriptional Regulation of cScratch2 during neurogenesis in the posterior neural tube. [Doctoral thesis (Systems Biology)]. Instituto de Ciências Biomédicas, Universidade de São Paulo, São Paulo; 2019.
\end{abstract}

Scratch2 is a transcription factor expressed in early post-mitotic neural cells that has a conserved role in survival, differentiation and migration. Scrt2 is expressed in a very restricted population of cells in the inner layer of the intermediate zone in the chick embryo, and this pattern remains conserved in vertebrates. The mechanisms that control its expression remain unknown and could contribute towards to our understanding of gene regulation during neural differentiation. Here we investigate the pre (enhancers and transcription factors) and posttranscriptional (miRNAs) regulatory mechanisms involved in Scrt2 regulation. We performed an in silico analysis and identified 1) a potential conserved cis-element (E1) in both chicken and mouse genome that could be involved in Scrt2 expression; 2) Ascl1, Brn2 and Sox2 as putative upstream TFs in the gene cascade, and 3) binding sites in the Scrt2 3'UTR for miR$125 b,-200 b,-429,-211$ and -204 . We tested the biological function of the candidate regulatory region E1 and 3'UTR through electroporation in chick embryos. Modulation of E1driven transcription via TFs was tested in luciferase reporter assay in HEK293T cells. We also performed Chromosome Conformation Capture (3C) to verify interactions between E1 and cScrt2 promoter and CRISPR/Cas9 methodology to edit E1 and miRNAs target sites in cScrt2 $3^{\prime}$ UTR. Our results indicate that E1 is a neural enhancer, driving Scrt2 expression, possibly in the equatorial neural tube domain. The overexpression of selected TFs in the neural tube increased cScr2 expression in the dorsal portion of the neural tube and decreased the size of some differentiated cells subpopulations in the neural tube. Moreover, the CRISPR-mediated edition of miRNAs target sites increased Scrt2 expression, suggesting a possible role for miR$125 \mathrm{~b}$ and $-200 \mathrm{~b}$ in post-transcriptional regulation of cScrt2. In conclusion, we propose that Scrt2 expression domain is generated by the conjunction of pre and post-transcriptional regulatory mechanisms. In this scenario, E1 could modulate cScrt2 transcription through Ascl1 and Brn2 transcription factors. After transcription, the levels of $c S c r t 2$ transcripts would be further delimited by the binding of miR-125b and -200b in the 3'UTR.

Keywords: Neurogenesis. Scratch. Gene regulation. Cis-elements. miRNA. 


\section{INTRODUÇÃO GERAL}

\section{Neurogênese no tubo neural}

O processo de neurogênese ocorre inicialmente pela ação inibitória de proteínas secretadas pela notocorda subjacente sobre proteínas da família BMP localizadas na ectoderme. A porção da ectoderme BMP-negativa - e centralizada -, agora passa a chamar-se de neuroectoderme ou placa neural. Com a progressão do desenvolvimento, as células mais mediais da placa neural sofrem constrição apical, invaginando e formando o sulco neural, ao passo que as bordas da placa neural se elevam para fundir-se na região dorsal. Com a fusão das dobras neurais, há a formação da epiderme (oriunda da ectoderme não-neural lateral à placa neural) na região dorsal, fechamento do tubo neural e, posteriormente, a liberação de um grupo de células migratórias localizadas na região dorsal do tubo neural, chamadas de células da crista neural (Bronner-Fraser, 1986).

Histologicamente, a placa neural é formada por células colunares, espessadas após indução pela notocorda (Smith e Schoenwolf, 1997), e que conferem ao tecido a caracterização de epitelial pseudoestratificado, também conhecido como neuroepitélio. As células neuroepiteliais possuem prolongamentos que as mantêm aderidas desde a membrana basal (mais periférica) até a membrana apical (mais interna), além de possuírem núcleos migratórios. A migração dos núcleos ao longo do citoplasma e sua posição no eixo centroperiférico do tubo neural varia extensivamente de acordo com o ciclo celular, estando ambos fortemente correlacionados no processo chamado migração nuclear intercinética (Ashwell, 2009). Durante a fase $S$ do ciclo celular, o núcleo está localizado mais próximo da membrana basal. À medida que entra em fase $G_{2}$, o núcleo se desloca para a margem oposta e, ao atingila, sofre mitose (fase $M$ ). Estas células são responsáveis pela autorrenovação da zona ventricular, além de gerar progenitores intermediários. A decisão de qual destino celular tomar, é dado pela orientação do fuso mitótico e expressão da via Notch, que mantém as células em estado proliferativo.

Após início do processo de diferenciação, pode-se observar a regionalização do tubo neural em camadas, sendo a camada inicial formada por células neuroepiteliais. Posteriormente, essa camada localizada ao redor do canal neural, passa a ser chamada de zona ventricular (Fig. 1). As células engajadas a diferenciar-se, saem do ciclo celular e migram 
para camadas mais periféricas. O progressivo acúmulo de células pós-mitóticas logo após a zona ventricular caracteriza a zona intermediária (Fig. 1). À medida em que mais células se diferenciam e migram, novas camadas mais periféricas são criadas. A camada seguinte à zona intermediária é chamada de zona do manto (Fig. 1), onde são encontradas células diferenciadas, tanto neurônios quanto células da glia, e corpos celulares de motoneurônios (Ashwell, 2009).
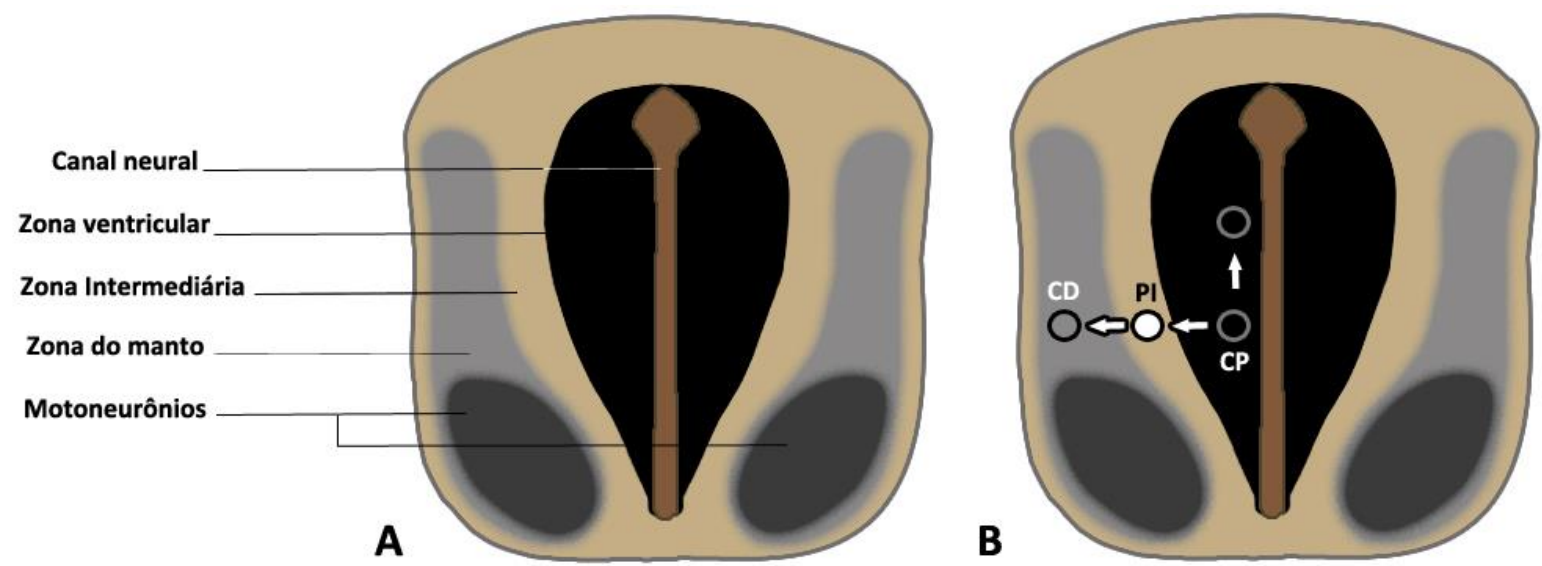

Figura 1: llustração de corte transversal do tubo neural. (A) Indicação das subdivisões adquiridas pelo tubo neural com a progressão do desenvolvimento. Centralmente está localizado o canal neural (em marrom escuro), seguido da zona ventricular, contendo as células proliferativas (em preto). Adjacente a esta última, no sentido centro-periférico, estão as zonas intermediária e do manto, respectivamente.

\section{Egresso do ciclo e destino celular}

A divisão celular e a diferenciação não ocorrem simultaneamente, havendo diversos mecanismos envolvidos desde o ciclo celular até a célula diferenciada. A transição de uma célula proliferativa para o estado pós-mitótico é um processo intensamente regulado, com vários pontos de checagem, e coordenado pela atividade de ciclinas e quinases (Molina e Pituello, 2017). Nesse processo, os reguladores-chave são expressos em tipos celulares específicos, mas algumas vias como Notch, Wnt e seus fatores de transcrição (FTs) estão presentes em diversos tecidos (Kaldis e Richardson, 2012). No contexto neural, foi proposto durante a neurogênese em zebrafish e em galinhas que a migração apicobasal do núcleo expõe o núcleo a variações de sinais da via Notch, regulando a neurogênese (Murciano et al.,2002; Del Bene et al.,2008).

Além disso, é sabido que a via Notch também está intimamente envolvida na ativação paralela de genes proneurais, determinando o conceito de "inibição lateral". Células que expressam o transcriptoma proneural (ex. Ascl1, Ngn2; Bertrand, Castro and Guillemot, 2002), 
ativam a expressão do ligante Delta que, por ser uma proteína de membrana, sinaliza a ativação da via Notch na célula lateral. Notch é uma proteína transmembrana, evolutivamente conservada, que atua por interações celulares locais (Rand, Lake e Artavanis-Tsakonas, 1999). Dentre os alvos dessa via, estão os FTs Hes (Hairy-Enhancer of Split) que inibem a expressão de genes proneurais, mantendo as células em estado indiferenciado (Louvi e ArtavanisTsakonas, 2006). Nesse contexto, foi visto em Drosophila que Scrt reprime a expressão de genes-alvo da via Notch interagindo em regiões promotoras (Fig. 3; Ramat et al.,2016). A consequência desse processo de inibição lateral é o egresso do ciclo celular.

Outro fator responsável pela repressão da via Notch são os fatores de transcrição bHLH Neurogenina 1/2 (Ngn1 ou Ngn2). É sabido que esses FTs controlam múltiplos passos da neurogênese, incluindo a saída do ciclo celular, comprometimento neuronal e início da diferenciação neural (Perez, Rebelo e Anderson, 1999; Bertrand, Castro e Guillemot, 2002). Quando os níveis de Ngn 1/2 aumentam, ativa a expressão dos ligantes de Notch, como Delta1 (DII1), Jagged1 (Jag1) e Jagged2 (Jag2) que por sua vezestas ativam a sinalização da via Notch nas células vizinhas (Madarsz, 2013). Ao mesmo tempo em que dispara a manutenção do estado proliferativo nas células vizinhas, atua na determinação do destino neural na célula em que está sendo expresso. Do mesmo modo atua Ascl1, outro FT do tipo bHLH.

O ciclo celular tem sido descrito como um processo que determina o destino celular. Foi visto que Ngn2 atua na repressão de outros diversos alvos envolvidos na progressão do ciclo celular, como Cond1 e das ciclinas Ccne1/2 (Ciclina E1 e E2). Essas ciclinas estão envolvidas nas fases G1 e S do ciclo celular, e tiveram sua expressão reduzida por Ngn2 (Lacomme et al.,2012). Assim, a saída do ciclo celular ocorre inicialmente pela repressão de ciclinas específicas nas fases G1 e S, por Ngn2, seguida da ativação de genes para diferenciação tardia, como Pax6 e Olig2, em um estado pós-mitótico. Um estudo em Xenopus, demonstrou que células progenitoras neurais apresentam altos níveis de Cdks. Essas enzimas atuam na fosforilação de Ngn2, tornando-a inativa no seu papel de determinar o início da diferenciação neural. A atividade de $\mathrm{Ngn} 2$ gradualmente retorna à medida em que as Cdks perdem atividade e Ngn2 é desfosforilada (Ali et al.,2011; Hardwick e Philpott, 2014). Com a Ngn2 inativa, a fase G1 é estendida. De forma oposta, com o aumento da atividade de Ngn2, a fase G1 é reduzida e há a ativação de genes-alvo proneurais, levando à diferenciação. 
Uma outra família gênica que participa no processo de determinação do estado proliferativo é a Sox ( $\underline{r} r y$-related HMG box). Basicamente, essa família é subdividida em dos grupos: B1, com Sox1 a Sox3 e B2, contendo Sox14 e Sox21. O primeiro grupo é conhecido por manter as células em estado proliferativo, enquanto o segundo, em promover a diferenciação neural. Sox2 é um dos fatores determinantes, junto a Oct4 (octamer-binding transcription factor 4), Klf4 (Kruppel-like factor 4) e Myc (Myelocytomatosis) na conversão de células somáticas ao estado pluripotente (Takahashi and Yamanaka, 2006). Nesse sentido, foi visto que Sox2 é capaz de atuar como fator pioneiro, durante a reprogramação celular, acessando a cromatina ainda fechada, assim como Ascl1 (Soufi, Donahue e Zaret, 2012). Em Xenopus, a superexpressão de Sox3 aumenta a expressão de Sox2 e geminina, uma proteína inibidora da replicação do DNA (Rogers et al.,2009), expressa nas fases S a M do ciclo celular, especialmente na neurogênese (Kroll, Kristen, 2007). Por outro lado, foi visto em células tumorais que Sox2 causa a redução da proliferação pela inibição da via mTor (Liu et al.,2013). Um outro trabalho, também em câncer, demonstrou que a superexpressão de Sox 2 promove a saída do ciclo celular por reprimir a ciclina D1 (Ccnd1), além de inibir a migração e invasão (Luo et al.,2018).

De modo geral, isso sugere que a saída do ciclo celular e a determinação de subtipos celulares no início do processo de diferenciação dá-se pelo acoplamento desses processos ocorrendo em paralelo.

\section{Cascata gênica no desenvolvimento neural}

Concomitante à migração radial de células recém-egressas do ciclo celular e a disposição centro-periférica, há a padronização de diferentes tipos neuronais no eixo dorsoventral do tubo neural através da atuação conjunta de morfógenos produzidos na ectoderme (dorsal) e na notocorda (ventral). De modo geral, a porção dorsal do tubo neural irá gerar neurônios sensoriais. Ventralmente a estes são caracterizadas seis camadas de diferenciação em interneurônios, uma camada de motoneurônios e uma última de interneurônios comissurais. Os eventos para geração de subtipos neurais específicos são regidos por uma cascata molecular bem definida, que também está intimamente ligada ao processo de migração neural (Ge et al.,2006). Em paralelo a este processo migratório, há a ativação sequencial e precisa de genes que regulam a transição do estado proliferativo para a 
diferenciação pós-mitótica (Corral e Storey, 2001). Dessa forma, o destino das células proliferativas poderá ser determinado de acordo com seu perfil particular de expressão gênica resultante da ativação e/ou repressão de genes. Isto, posteriormente, definirá a localização espaço-temporal de subtipos neurais específicos que subdividem o tubo neural em domínios distintos.

Este tipo de organização permite a segregação espacial de genes marcadores e atuantes para etapas distintas da neurogênese, como por exemplo, a expressão de Notch em células progenitoras, localizadas na zona ventricular; Sox3 e Ngn2, em células recém-egressas do ciclo celular, nas zonas subventricular e intermediária, imediatamente mais externa ao domínio de expressão de Notch; Brn2, uma proteína da família POU de fatores de transcrição, é expressa desde a zona ventricular até a intermediária, sendo responsável pelo egresso do ciclo celular de progenitores neurais e pelo início da diferenciação neural e migração radial (Fig. 3; Tanaka et al.,2004; Castro et al.,2006). Outro exemplo é NeuroD4/NeuroM, uma proteína expressa na zona intermediária, em células pós-mitóticas e em início de diferenciação (Fig. 3).

E por último, há a expressão de beta-Tubulina III (Lee et al.,1990), um marcador de diferenciação tardia, expresso por células localizadas na região mais periférica do tubo neural, ou Isletl (Ericson et al.,1992), na região ventral da zona do manto onde contém os precursores de motoneurônios.

\section{Scratch2 no desenvolvimento neural}

Incluído neste contexto de diferenciação centro-periférica, encontramos o gene Scratch2 (Scrt2). Este gene pertence à família Scratch, inserida na superfamília Snail/Slug de fatores de transcrição, juntamente à família Snail. A primeira possui os membros Scratch1 e Scratch2, enquanto a segunda possui os fatores Snail1, Snail2/Slug e Snail3/Smuc (Fig. 2; Barrallo-Gimeno e Nieto, 2005; Chiang e Ayyanathan, 2012).

Os membros desta superfamília possuem a região C-terminal conservada, apresentando 4 a 6 domínios zinc-fingers, que auxiliam na ligação da proteína na curvatura maior do DNA em sítios E-box (CAGGTG) (Nakakura et al.,2001; Nieto, 2002) e, que também são reconhecidos por fatores de transcrição bHLH (Nakakura et al.,2001). Na outra extremidade, há a presença conservada do domínio SNAG presente em vertebrados (Grimes 
et al.,1996; Eric K. Nakakura et al.,2001), em Snail1 de equinodermos e cefalocordados (Langeland et al.,1998) e em Scratch de Drosophila (Roark et al.,1995). Este domínio é necessário para que Scrt atue como repressor transcricional (Grimes et al.,1996; Dam et al.,2011). E ainda, o que diferencia a família Scratch das outras proteínas da família Snail é a presença do domínio SCRATCH entre os domínios SNAG e zinc-finger (Fig. 2; Manzanares, Locascio e Nieto, 2001; Vieceli et al.,2013).

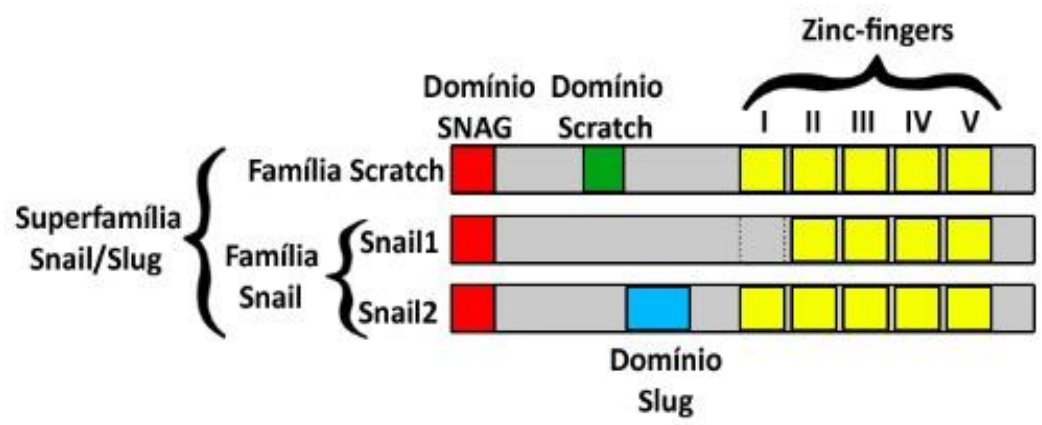

Figura 2: Esquema da estrutura proteica dos membros da superfamília Snail/Slug. Todos genes que compõem esta superfamília apresentam o domínio repressor SNAG na região N-terminal e na extremidade C-terminal, de 4 a 6 domínios zinc-finger de ligação ao DNA. Os domínios Scratch e Slug são os diferenciais entre as famílias Scratch e Snail, respectivamente, sendo o domínio Slug presente apenas em Snail2.

A expressão de Scrt2 tem sido relatada relacionada ao desenvolvimento do sistema nervoso. Trabalhos anteriores caracterizaram Scrt2 como um elemento relevante na diferenciação neural pós-mitótica inicial e na migração celular. O primeiro relato demonstra a redução do número de células fotorreceptoras nos olhos de moscas adultas nocauteadas para Scrt2 (Roark et al.,1995). Esse fenótipo pôde ser agravado com o duplo knockout para o gene deadpan (dpn), homólogo de membros da família HES de fatores de transcrição bHLH em vertebrados (Roark et al.,1995; Wallace, Liu e Vaessin, 2000), havendo redução drástica no número de neurônios (Roark et al.,1995).

Além disso, a expressão ectópica de Scrt2 dispara a formação de neurônios supranumerários provenientes do surgimento precoce de progenitores neurais (Roark et al.,1995). Já mais recentemente, Ramat et al., (2016), demonstraram que Scrt regula o destino de precursores neurais, mantendo as células fora da via de sinalização Notch, por se ligar à região promotora de genes-alvo da via e reprimi-los.

Em outro invertebrado, no nemátodo C. elegans, foi visto que o homólogo de Scrt2, Ces-1 (Metzstein e Horvitz, 1999), está relacionado à inibição da apoptose de neurônios na 
região da faringe, possivelmente pela repressão de dois outros genes que atuam na morte celular, ced-3 e ced-4 (Ellis e Horvitz, 1991; Liu e Hengartnet, 1999). Além disso, o processo de apoptose programada foi inibido por Ces-1 após a divisão celular assimétrica dos progenitores neurais (Hatzold e Conradt, 2008), gerando mais neurônios. Um outro mecanismo recentemente descrito em $C$. elegans é o bloqueio da progressão do ciclo celular em progenitores motoneurais pela ligação a um elemento cis localizado a 4.8 kb acima de Cdc25.2 e, consequentemente, reprimindo a transcrição desse gene (Yan et al.,2013).

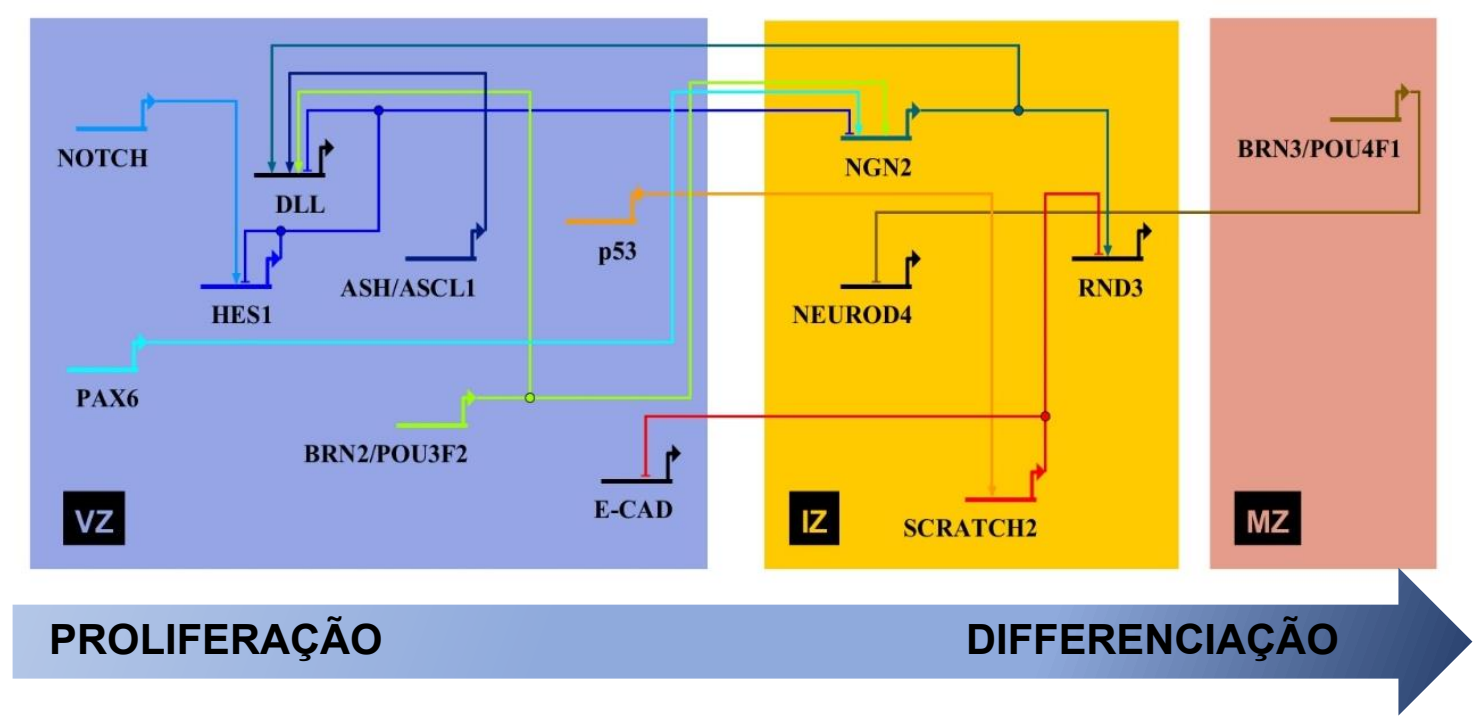

Figura 3: Resumo da cascata gênica ao qual Scratch2 está inserido, com alvos de diversos modelos. Na zona ventricular (VZ, azul) ocorre a expressão de genes associados à proliferação. Na zona intermediária (IZ, amarelo), os genes associados à transição da saída do ciclo celular e início de diferenciação. Scratch2 está inserido nesse domínio. Na zona do manto (MZ, rosa), estão os genes associados à diferenciação neural.

Em vertebrados, especificamente em zebrafish (Danio rerio), a expressão de Scrt2 é restrita à população em início de diferenciação (Dam et al.,2011). Em camundongos, mScrt2 está presente em células recém-egressas do ciclo celular, na zona intermediária do tubo neural e também do telencéfalo (Marín e Nieto, 2006; Paul et al.,2012; Itoh et al.,2013). Além disso, mScrt2 também foi observado no epitélio retiniano (Nakakura et al.,2001). Scrt2 tem sido descrito como uma molécula antiapoptótica (Metzstein e Horvitz, 1999; Nakakura et al.,2001; Hatzold e Conradt, 2008). Contudo, a expressão de Scrt2 em camundongos está associada a um novo papel, atuando no início da migração de células do neocórtex e da zona subventricular do hipocampo, sendo estas últimas as responsáveis pela origem de células da glia (Paul et al.,2012; Itoh et al.,2013), demonstrando sua importância na neurogênese. 
Por fim, em galinha (Gallus gallus) cScrt2 foi descrito, assim como nos outros modelos, como uma proteína restrita ao sistema nervoso, expressa em toda a extensão do tubo neural, além de gânglios craniais e da raiz dorsal (Fig. 4F; Vieceli et al.,2013). Em estágios iniciais do desenvolvimento (HH15), Scrt2 é expresso em células pós-mitóticas do tubo neural, numa população muito restrita (Fig. 4A) localizadas na periferia do tubo neural. Posteriormente, com a progressão do desenvolvimento, as células pós-mitóticas migram centrifugamente, ocupando camadas cada vez mais externas do tubo neural (Fig. 4C). Após o início da diferenciação das células pós-mitóticas, há a migração e sublocalização na zona do manto e deslocamento do padrão de expressão de $c S c r t 2$, antes periférico, para a zona intermediária. Por meio de hibridação in situ dupla para marcadores moleculares conhecidos, Vieceli e colaboradores (2013), verificaram que a expressão de cScrt2, de fato, ocorre em células pósmitóticas e em início de diferenciação por não possuir sobreposição de cScrt2 com marcadores de proliferação (ex. BrdU e Sox3) ou de diferenciação (SCG10).

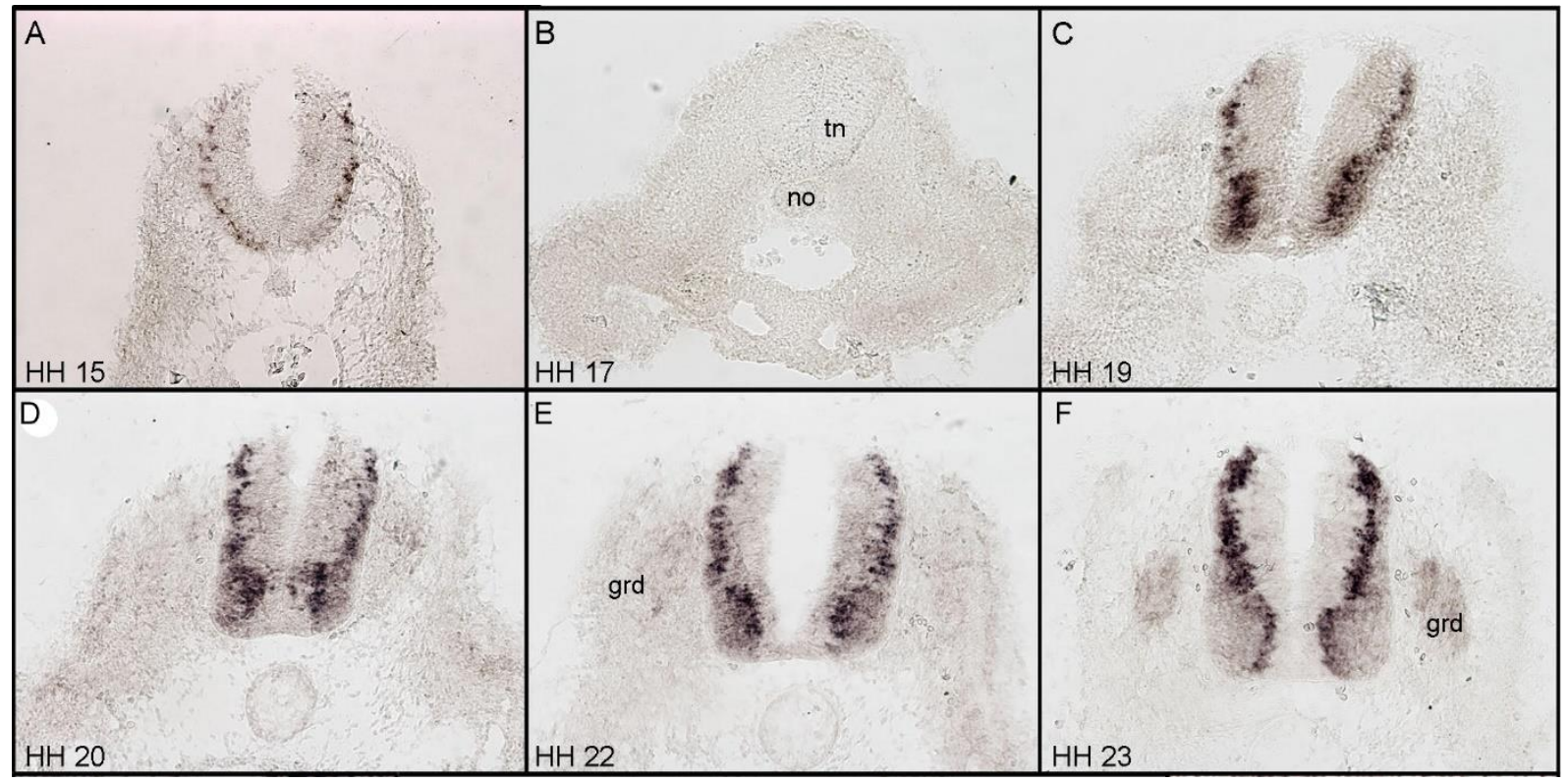

Figura 4: Expressão embrionária de cScrt2. (A-F) Hibridação in situ para cScrt2 em cortes transversais de embriões de galinha em HH15 (A), HH17 (B), HH19 (C), HH20 (D), HH22 (E) e HH23 (F). Em (B) foi utilizada uma sonda senso para cScrt2 como controle. grd, gânglio da raiz dorsal. Adaptado de: Vieceli et al.,2014.

O padrão espacial bem delimitado de Scrt2 sugere que sua expressão seja regulada em diversos níveis durante a neurogênese. Os elementos envolvidos na regulação da expressão gênica representam a manutenção, refinamento ou aquisição de novos papéis para os genes aos quais estão associados. Evolutivamente, isso significa que um gene pode ter sua função 
ou local de expressão modificados de acordo com os elementos que o regulam, levando à processos de adaptação e, cumulativamente, especiação.

Dessa forma, aqui investigamos possíveis mecanismos de regulação de expressão pré e pós-transcricional. Buscamos identificar tanto elementos cis quanto trans em mecanismos de regulação pré- e pós-transcricionais envolvidos na expressão de Scrt2. Elementos trans são também conhecidos como fatores de transcrição (FT), ou seja, proteínas que reconhecem sequências específicas de DNA, atuando junto à maquinaria de transcrição na ativação ou repressão gênica. As sequências de DNA/sítios-alvo que os FTs reconhecem também são denominadas de motifs e estão inseridas em fragmentos maiores de DNA com papel regulatório, os elementos cis. Esse último, por sua vez, é também conhecido como enhancer, regiões de DNA que atuam na modulação da expressão gênica pela ação combinada de elementos trans e maquinaria de transcrição.

O mecanismo de regulação pós-transcricional aqui abordado é centrado em miRNAs. Diferentemente dos fatores de transcrição, a maioria dos miRNAs atua póstranscricionalmente, impedindo a tradução do mRNA-alvo através da sua hibridação com a porção 3'UTR do mRNA e direcionando este para degradação. Considerando esse contexo, os miRNAs também são considerados elementos trans, e seus sítios-alvo como elementos cisregulatórios. 


\section{CONCLUSÃO GERAL}

Especificamente, concluímos:

1) Tanto mE1 quanto cE1 (USE), possuem atividade enhancer no tubo neural posterior embrionário.

2) O ensaio $3 C$ revelou que cE1 está interagindo com o promotor de cScrt2, além de revelar um novo elemento-cis (Ep2) possivelmente envolvido na regulação de cScrt2.

3) A deleção de cE1 causa alteração na morfologia dorsoventral do tubo neural e redução da expressão de $c S c r t 2$.

4) Ascl1 reconhece cE1 através do motif de heterodimerização "Ascl1/Brn2".

5) A superexpressão conjunta de $A s c 11$ e Brn2 aumenta a expressão de cScrt2 na região dorsal do tubo neural e reduz o domínio de células diferenciadas.

6) Os miRNAs $-125 b$ e $-200 b$ são expressos no tubo neural em complementariedade temporal a cScrt2.

7) miR-125b e -200b regulam cScrt2 pós-transcricionalmente por meio de sítios localizados em sua 3'UTR.

8) cScrt2 atua na modulação de genes associados a diversos processos celulares, reconhecendo regiões codificantes e não codificantes no genoma de galinha. 


\section{REFERÊNCIAS}

Agarwal, V. et al. (2015) 'Predicting effective microRNA target sites in mammalian mRNAs', elife, 4. doi: 10.7554/eLife.05005.

Akamatsu, W. et al. (1999) 'Mammalian ELAV-like neuronal RNA-binding proteins HuB and HuC promote neuronal development in both the central and the peripheral nervous systems', Proceedings of the National Academy of Sciences, 96(17), pp. 9885-9890. doi: 10.1073/pnas.96.17.9885.

Ali, F. et al. (2011) 'Cell cycle-regulated multi-site phosphorylation of Neurogenin 2 coordinates cell cycling with differentiation during neurogenesis', Development, 138(19), pp. 4267-4277. doi: 10.1242/dev.067900.

Allfrey, V. G., Faulkner, R. and Mirsky, A. E. (1964) 'ACETYLATION AND METHYLATION OF HISTONES AND THEIR POSSIBLE ROLE IN THE REGULATION OF RNA SYNTHESIS', Proceedings of the National Academy of Sciences, 51(5), pp. 786-794. doi: 10.1073/pnas.51.5.786.

Anderson, E. et al. (2014) 'Mapping the Shh long-range regulatory domain', Development, 141(20), pp. 3934-3943. doi: 10.1242/dev.108480.

Aoki, J. (1991) 'Neural cell adhesion molecule mediates contact-dependent inhibition of growth of near-diploid mouse fibroblast cell line m5S/1M', The Journal of Cell Biology, 115(6), pp. 1751-1761. doi: 10.1083/jcb.115.6.1751.

Arnaudo, A. M. and Garcia, B. A. (2013) 'Proteomic characterization of novel histone posttranslational modifications', Epigenetics \& Chromatin, 6(1), p. 24. doi: 10.1186/1756-8935-624.

Ashwell, K. W. (2009) 'Development of the Spinal Cord', in The Spinal Cord. Elsevier, pp. 8-16. doi: 10.1016/B978-0-12-374247-6.50006-7.

Atkinson, T. J. and Halfon, M. S. (2014) 'REGULATION OF GENE EXPRESSION IN THE GENOMIC CONTEXT', Computational and Structural Biotechnology Journal, 9(13), p. e201401001. doi: 10.5936/csbj.201401001.

Avilés, E. C., Wilson, N. H. and Stoeckli, E. T. (2013) 'Sonic hedgehog and Wnt: antagonists in morphogenesis but collaborators in axon guidance', Frontiers in Cellular Neuroscience, 7(June), pp. 1-17. doi: 10.3389/fncel.2013.00086.

Bally-Cuif, L., Goridis, C. and Santoni, M. J. (1993) 'The mouse NCAM gene displays a biphasic expression pattern during neural tube development.', Development (Cambridge, England), 117(2), pp. 543-52. doi: 8330525. 
Barrallo-Gimeno, A. and Nieto, M. (2005) 'The Snail genes as inducers of cell movement and survival: implications in development and cancer', Development, 132(14), pp. 3151-3161. doi: 10.1242/dev.01907.

Bell, G. W., Yatskievych, T. A. and Antin, P. B. (2004) 'GEISHA, a whole-mount in situ hybridization gene expression screen in chicken embryos', Developmental Dynamics, 229(3), pp. 677-687. doi: 10.1002/dvdy.10503.

Del Bene, F. et al. (2008) 'Regulation of Neurogenesis by Interkinetic Nuclear Migration through an Apical-Basal Notch Gradient', Cell, 134(6), pp. 1055-1065. doi: 10.1016/j.cell.2008.07.017.

Bergsland, M. et al. (2006) 'The establishment of neuronal properties is controlled by Sox4 and Sox11', Genes \& Development, 20(24), pp. 3475-3486. doi: 10.1101/gad.403406.

Bertrand, N., Castro, D. S. and Guillemot, F. (2002) 'Proneural genes and the specification of neural cell types', Nature Reviews Neuroscience, 3(7), pp. 517-530. doi: 10.1038/nrn874.

Bhattacharya, D. et al. (2018) 'Control of neural crest multipotency by wnt signaling and the Lin28/let-7 axis', eLife, 7, pp. 1-24. doi: 10.7554/eLife.40556.

Billin, A. N., Cockerill, K. A. and Poole, S. J. (1991) 'Isolation of a family of Drosophila POU domain genes expressed in early development', Mechanisms of Development, 34(2-3), pp. 75-84. doi: 10.1016/0925-4773(91)90045-8.

Biswas, A. and Brown, C. M. (2014) 'Scan for Motifs: a webserver for the analysis of posttranscriptional regulatory elements in the $3^{\prime}$ untranslated regions ( $3^{\prime}$ UTRs) of mRNAs', BMC Bioinformatics, 15(1), p. 174. doi: 10.1186/1471-2105-15-174.

Black, J. C., Van Rechem, C. and Whetstine, J. R. (2012) 'Histone Lysine Methylation Dynamics: Establishment, Regulation, and Biological Impact', Molecular Cell, 48(4), pp. 491-507. doi: 10.1016/j.molcel.2012.11.006.

Boissart, C. et al. (2012) 'miR-125 potentiates early neural specification of human embryonic stem cells', Development, 139(7), pp. 1247-1257. doi: 10.1242/dev.073627.

Boros, J. et al. (2014) 'Polycomb repressive complex 2 and H3K27me3 cooperate with H3K9 methylation to maintain heterochromatin protein $1 \alpha$ at chromatin.', Molecular and cellular biology, 34(19), pp. 3662-74. doi: 10.1128/MCB.00205-14.

Briscoe, J. and Small, S. (2015) 'Morphogen rules: design principles of gradient-mediated embryo patterning.', Development (Cambridge, England), 142(23), pp. 3996-4009. doi: 10.1242/dev.129452.

Bronner-Fraser, M. (1986) 'Analysis of the early stages of trunk neural crest migration in avian 
embryos using monoclonal antibody HNK-1', Developmental Biology, 115(1), pp. 44-55. doi: 10.1016/0012-1606(86)90226-5.

Bylund, M. et al. (2003) 'Vertebrate neurogenesis is counteracted by Sox1-3 activity', Nature Neuroscience, 6(11), pp. 1162-1168. doi: 10.1038/nn1131.

Cai, X., Hagedorn, C. and Cullen, B. (2004) 'Human microRNAs are processed from capped, polyadenylated transcripts that can also function as mRNAs', RNA, 10(12), pp. 1957-1966. doi: 10.1261/rna.7135204

Cai, Y. et al. (2019) 'H3K27me3-rich genomic regions can function as silencers to repress gene expression via chromatin interactions', bioRxiv, 9664(65), p. 684712. doi: 10.1101/684712.

Calo, E. and Wysocka, J. (2013) 'Modification of Enhancer Chromatin: What, How, and Why?', Molecular Cell, 49(5), pp. 825-837. doi: 10.1016/j.molcel.2013.01.038.

Casarosa, S., Fode, C. and Guillemot, F. (1999) 'Mash1 regulates neurogenesis in the ventral telencephalon.', Development (Cambridge, England), 126(3), pp. 525-34. Available at: http://www.ncbi.nlm.nih.gov/pubmed/9876181.

Castro, D. S. et al. (2006) 'Proneural bHLH and Brn Proteins Coregulate a Neurogenic Program through Cooperative Binding to a Conserved DNA Motif', Developmental Cell, 11(6), pp. 831844. doi: 10.1016/j.devcel.2006.10.006.

Castro, D. S. et al. (2011) 'A novel function of the proneural factor Ascl1 in progenitor proliferation identified by genome-wide characterization of its targets', Genes and Development, 25(9), pp. 930-945. doi: 10.1101/gad.627811.

Caviness, V. S., Takahashi, T. and Nowakowski, R. S. (1995) 'Numbers, time and neocortical neuronogenesis: a general developmental and evolutionary model', Trends in Neurosciences, 18(9), pp. 379-383. doi: 10.1016/0166-2236(95)93933-0.

Cedar, H. and Bergman, Y. (2009) 'Linking DNA methylation and histone modification: Patterns and paradigms', Nature Reviews Genetics, 10(5), pp. 295-304. doi: 10.1038/nrg2540.

Chen, K. and Rajewsky, N. (2007) 'The evolution of gene regulation by transcription factors and microRNAs', Nature Reviews Genetics, 8(2), pp. 93-103. doi: 10.1038/nrg1990.

Chen, X. et al. (2015) 'MiR-125b protects against ethanol-induced apoptosis in neural crest cells and mouse embryos by targeting Bak 1 and PUMA', Experimental Neurology, 271, pp. 104-111. doi: 10.1016/j.expneurol.2015.04.026.

Chiang, C. and Ayyanathan, K. (2012) 'Characterization of the E-box binding affinity to SNAGzinc finger proteins', Molecular Biology, 46(6), pp. 809-816. doi: 10.1134/S0026893312060027. 
Choi, P. S. et al. (2008) 'Members of the miRNA-200 Family Regulate Olfactory Neurogenesis', Neuron, 57(1), pp. 41-55. doi: 10.1016/j.neuron.2007.11.018.

Cirillo, L. A. et al. (2002) 'Opening of compacted chromatin by early developmental transcription factors HNF3 (FoxA) and GATA-4.', Moleular cell, 9(2), pp. 279-89. Available at: http://www.ncbi.nlm.nih.gov/pubmed/11864602.

Cole, S. J., Bradford, D. and Cooper, H. M. (2007) 'Neogenin: A multi-functional receptor regulating diverse developmental processes', The International Journal of Biochemistry \& Cell Biology, 39(9), pp. 1569-1575. doi: 10.1016/j.biocel.2006.11.009.

Corral, R. D. del and Storey, K. G. (2001) 'Markers in vertebrate neurogenesis', Nature Reviews Neuroscience, 2(11), pp. 835-839. doi: 10.1038/35097587.

Creyghton, M. P. et al. (2010) 'Histone H3K27ac separates active from poised enhancers and predicts developmental state', Proceedings of the National Academy of Sciences, 107(50), pp. 21931-21936. doi: 10.1073/pnas.1016071107.

Cui, Y. et al. (2012) 'MiR-125b orchestrates cell proliferation, differentiation and migration in neural stem/progenitor cells by targeting Nestin', BMC Neuroscience. BMC Neuroscience, 13(1), p. 1. doi: 10.1186/1471-2202-13-116.

Dallman, J. et al. (2004) 'A Conserved Role But Different Partners for the Transcriptional Corepressor CoREST in Fly and Mammalian Nervous System Formation', Journal of Neuroscience, 24(32), pp. 7186-7193. doi: 10.1523/JNEUROSCI.0238-04.2004.

Dam, T. M. T. et al. (2011) 'Neuron-specific expression of scratch genes during early zebrafish development', Molecules and Cells, 31(5), pp. 471-475. doi: 10.1007/s10059-011-0052-4.

Darnell, D. K. et al. (2006) 'MicroRNA expression during chick embryo development', Developmental Dynamics, 235(11), pp. 3156-3165. doi: 10.1002/dvdy.20956.

Darnell, D. K. et al. (2007) 'GEISHA: an in situ hybridization gene expression resource for the chicken embryo', Cytogenetic and Genome Research, 117(1-4), pp. 30-35. doi: 10.1159/000103162.

Delile, J. et al. (2019) 'Single cell transcriptomics reveals spatial and temporal dynamics of gene expression in the developing mouse spinal cord', Development, 146(12), p. dev173807. doi: 10.1242/dev.173807.

Diaz Quiroz, J. F. et al. (2014) 'Precise control of miR-125b levels is required to create a regeneration-permissive environment after spinal cord injury: a cross-species comparison between salamander and rat', Disease Models \& Mechanisms, 7(6), pp. 601-611. doi: 10.1242/dmm.014837. 
Dichmann, D. S. and Harland, R. M. (2011) 'Nkx6 genes pattern the frog neural plate and Nkx6.1 is necessary for motoneuron axon projection', Developmental Biology, 349(2), pp. 378-386. doi: 10.1016/j.ydbio.2010.10.030.

Ding, X. et al. (2013) 'Signaling between Transforming Growth Factor $\beta$ (TGF- $\beta$ ) and Transcription Factor SNAI2 Represses Expression of MicroRNA miR-203 to Promote EpithelialMesenchymal Transition and Tumor Metastasis', Journal of Biological Chemistry, 288(15), pp. 10241-10253. doi: 10.1074/jbc.M112.443655.

Dixit, R. et al. (2014) 'Neurog1 and Neurog2 Control Two Waves of Neuronal Differentiation in the Piriform Cortex', Journal of Neuroscience, 34(2), pp. 539-553. doi: 10.1523/JNEUROSCI.0614-13.2014.

Doherty, P. et al. (1991) 'Morphoregulatory activities of NCAM and N-cadherin can be accounted for by $\mathrm{G}$ protein-dependent activation of L- and N-type neuronal Ca2+ channels', Cell, 67(1), pp. 21-33. doi: 10.1016/0092-8674(91)90569-K.

Dominguez, M. H., Ayoub, A. E. and Rakic, P. (2013) 'POU-III transcription factors (Brn1, Brn2, and Oct6) influence neurogenesis, molecular identity, and migratory destination of upperlayer cells of the cerebral cortex', Cerebral Cortex, 23(11), pp. 2632-2643. doi: $10.1093 /$ cercor/bhs252.

Le Dreau, G. et al. (2012) 'Canonical BMP7 activity is required for the generation of discrete neuronal populations in the dorsal spinal cord', Development, 139(2), pp. 259-268. doi: 10.1242/dev.074948.

Le Dréau, G. and Martí, E. (2012) 'Dorsal-ventral patterning of the neural tube: A tale of three signals', Developmental Neurobiology, 72(12), pp. 1471-1481. doi: 10.1002/dneu.22015.

Du, Z.-W. et al. (2013) 'miR-200 and miR-96 families repress neural induction from human embryonic stem cells', Development, 140(12), pp. 2611-2618. doi: 10.1242/dev.092809.

Duursma, A. M. et al. (2008) 'miR-148 targets human DNMT3b protein coding region', RNA, 14(5), pp. 872-877. doi: 10.1261/rna.972008.

Dykes, I. M. and Emanueli, C. (2017) 'Transcriptional and Post-transcriptional Gene Regulation by Long Non-coding RNA', Genomics, Proteomics \& Bioinformatics, 15(3), pp. 177-186. doi: 10.1016/j.gpb.2016.12.005.

Ebert, M. S., Neilson, J. R. and Sharp, P. A. (2007) 'MicroRNA sponges: competitive inhibitors of small RNAs in mammalian cells', Nature Methods, 4(9), pp. 721-726. doi: $10.1038 /$ nmeth1079.

El-Sherif, E. and Levine, M. (2016) 'Shadow Enhancers Mediate Dynamic Shifts of Gap Gene Expression in the Drosophila Embryo.', Current biology: CB, 26(9), pp. 1164-9. doi: 
10.1016/j.cub.2016.02.054.

Ellis, R. E. and Horvitz, H. R. (1991) 'Two C. elegans genes control the programmed deaths of specific cells in the pharynx.', Development (Cambridge, England), 112(2), pp. 591-603. Available at: http://www.ncbi.nlm.nih.gov/pubmed/1794327.

Ericson, J. et al. (1992) 'Early stages of motor neuron differentiation revealed by expression of homeobox gene Islet-1', Science, 256(5063), pp. 1555-1560. doi: 10.1126/science.1350865. Fan, J., Baeza, J. and Denu, J. M. (2016) 'Investigating Histone Acetylation Stoichiometry and Turnover Rate', in, pp. 125-148. doi: 10.1016/bs.mie.2016.01.007.

Fei, Q. et al. (2015) 'SETDB1 modulates PRC2 activity at developmental genes independently of H3K9 trimethylation in mouse ES cells.', Genome research, 25(9), pp. 1325-35. doi: 10.1101/gr.177576.114.

Feng, Y. P. et al. (2014) 'Expression analysis of differentially expressed miRNAs in male and female chicken embryos', Genetics and Molecular Research, 13(2), pp. 3060-3068. doi: 10.4238/2014.April.17.2.

Fode, C. et al. (2000) 'A role for neural determination genes in specifying the dorsoventral identity of telencephalic neurons', Genes and Development, 14(1), pp. 67-80. doi: 10.1101/gad.14.1.67.

Foster, D. J. et al. (2012) 'Comprehensive evaluation of canonical versus Dicer-substrate siRNA in vitro and in vivo', Rna, 18(3), pp. 557-568. doi: 10.1261/rna.031120.111.

Gandhi, S. et al. (2017) 'Optimization of CRISPR/Cas9 genome editing for loss-of-function in the early chick embryo', Developmental Biology. Elsevier Inc., 432(1), pp. 86-97. doi: 10.1016/j.ydbio.2017.08.036.

Gaudet, J. (2002) 'Regulation of Organogenesis by the Caenorhabditis elegans FoxA Protein PHA-4', Science, 295(5556), pp. 821-825. doi: 10.1126/science.1065175.

Ge, W. et al. (2006) 'Coupling of cell migration with neurogenesis by proneural bHLH factors', Proceedings of the National Academy of Sciences, 103(5), pp. 1319-1324. doi: 10.1073/pnas.0510419103.

Giovannone, D. et al. (2015) 'Chicken trunk neural crest migration visualized with HNK1', Acta Histochemica. Elsevier GmbH., 117(3), pp. 255-266. doi: 10.1016/j.acthis.2015.03.002.

Glazov, E. A. et al. (2008) 'A microRNA catalog of the developing chicken embryo identified by a deep sequencing approach', Genome Research, 18(6), pp. 957-964. doi: 10.1101/gr.074740.107.

Golla, J. P. et al. (2014) 'Carboxylation of cytosine (5caC) in the CG dinucleotide in the E-box 
motif (CGCAG |GTG) increases binding of the Tcf3|Ascl1 helix-loop-helix heterodimer 10-fold', Biochemical and Biophysical Research Communications, 449(2), pp. 248-255. doi: 10.1016/j.bbrc.2014.05.018.

Goridis, C. and Brunet, J.-F. (1992) 'NCAM: Structural diversity, function and regulation of expression', Seminars in Cell Biology, 3(3), pp. 189-197. doi: 10.1016/S1043-4682(10)800157.

Grimes, H. L. et al. (1996) 'The Gfi-1 proto-oncoprotein contains a novel transcriptional repressor domain, SNAG, and inhibits G1 arrest induced by interleukin-2 withdrawal.', Molecular and Cellular Biology, 16(11), pp. 6263-6272. doi: 10.1128/mcb.16.11.6263.

Groner, A. C. et al. (2010) 'KRAB-Zinc Finger Proteins and KAP1 Can Mediate Long-Range Transcriptional Repression through Heterochromatin Spreading', PLoS Genetics. Edited by H. D. Madhani, 6(3), p. e1000869. doi: 10.1371/journal.pgen.1000869.

Gross, D. S. and Garrard, W. T. (1988) 'Nuclease Hypersensitive Sites in Chromatin', Annual Review of Biochemistry, 57(1), pp. 159-197. doi: 10.1146/annurev.bi.57.070188.001111.

Gruner, H. et al. (2019) 'Precise removal of Calm1 long 3' UTR isoform by CRISPR-Cas9 genome editing impairs dorsal root ganglion development in mice', bioRxiv. doi: https://doi.org/10.1101/553990.

Grunstein, M. (1997) 'Histone acetylation in chromatin structure and transcription', Nature, 389(6649), pp. 349-352. doi: 10.1038/38664.

Gualdi, R. et al. (1996) 'Hepatic specification of the gut endoderm in vitro: cell signaling and transcriptional control.', Genes \& Development, 10(13), pp. 1670-1682. doi: 10.1101/gad.10.13.1670.

Guillemot, F. and Joyner, a L. (1993) 'Dynamic expression of the murine Achaete-Scute homologue Mash-1 in the developing nervous system.', Mechanisms of development, 42(3), pp. 171-85.

Guo, Y. et al. (2012) 'CTCF / cohesin-mediated DNA looping is required for protocadherin $\alpha$ promoter choice', 109(51). doi: 10.1073/pnas.1219280110.

Gusel'nikova, V. V. and Korzhevskiy, D. E. (2015) 'NeuN as a neuronal nuclear antigen and neuron differentiation marker', Acta Naturae, 7(2), pp. 42-47.

Hagege, H. et al. (2007) 'Quantitative analysis of chromosome conformation capture assays (3c-qpcr)', Nature Protocols, 2(7), pp. 1722-1733. doi: 10.1038/nprot.2007.243.

Hamburger, V. and Hamilton, H. L. (1992) 'A Series of Normal Stages in the Development of the Chick Embryo', Developmental Dynamics, 195, pp. 231-272. 
Han, K. and Manley, J. L. (1993) 'Functional domains of the Drosophila Engrailed protein.', The EMBO Journal, 12(7), pp. 2723-2733. doi: 10.1002/j.1460-2075.1993.tb05934.x.

Han, S. et al. (2018) 'The effects of alternative splicing on miRNA binding sites in bladder cancer', PLOS ONE. Edited by Y. Zheng, 13(1), p. e0190708. doi: 10.1371/journal.pone.0190708.

Hardwick, L. J. A. and Philpott, A. (2014) 'Nervous decision-making: to divide or differentiate', Trends in Genetics, 30(6), pp. 254-261. doi: 10.1016/j.tig.2014.04.001.

Hatzold, J. and Conradt, B. (2008) 'Control of Apoptosis by Asymmetric Cell Division', PLoS Biology. Edited by J. Ahringer, 6(4), p. e84. doi: 10.1371/journal.pbio.0060084.

He, X. et al. (1989) 'Expression of a large family of POU-domain regulatory genes in mammalian brain development', Nature, 340(6228), pp. 35-42. doi: 10.1038/340035a0.

Heintzman, N. D. et al. (2007) 'Distinct and predictive chromatin signatures of transcriptional promoters and enhancers in the human genome', Nature Genetics, 39(3), pp. 311-318. doi: $10.1038 /$ ng1966.

Henke, R. M. et al. (2009) 'Ascl1 and Neurog2 form novel complexes and regulate Delta-like3 (DII3) expression in the neural tube', Developmental Biology. Elsevier Inc., 328(2), pp. 529540. doi: 10.1016/j.ydbio.2009.01.007.

Herrup, K. and Yang, Y. (2007) 'Cell cycle regulation in the postmitotic neuron: oxymoron or new biology?', Nature Reviews Neuroscience, 8(5), pp. 368-378. doi: 10.1038/nrn2124.

Hirai, H., Tani, T. and Kikyo, N. (2010) 'Structure and functions of powerful transactivators: VP16, MyoD and FoxA', The International Journal of Developmental Biology, 54(11-12), pp. 1589-1596. doi: 10.1387/ijdb.103194hh.

Horton, S. et al. (1999) 'Correct Coordination of Neuronal Differentiation Events in Ventral Forebrain Requires the bHLH Factor MASH1', Molecular and Cellular Neuroscience, 14(4-5), pp. 355-369. doi: 10.1006/mcne.1999.0791.

Hutchins, A. P. and Pei, D. (2015) 'Transposable elements at the center of the crossroads between embryogenesis, embryonic stem cells, reprogramming, and long non-coding RNAs', Science Bulletin, 60(20), pp. 1722-1733. doi: 10.1007/s11434-015-0905-x.

Hyun, K. et al. (2017) 'Writing, erasing and reading histone lysine methylations', Experimental \& Molecular Medicine, 49(4), pp. e324-e324. doi: 10.1038/emm.2017.11.

Imayoshi, I. et al. (2013) 'Oscillatory control of factors determining multipotency and fate in mouse neural progenitors', Science, 342(6163), pp. 1203-1208. doi: 10.1126/science.1242366. 
Itoh, Y. et al. (2013) 'Scratch regulates neuronal migration onset via an epithelialmesenchymal transition-like mechanism', Nature Neuroscience. Nature Publishing Group, 16(4), pp. 416-425. doi: 10.1038/nn.3336.

Jeong, Y. (2006) 'A functional screen for sonic hedgehog regulatory elements across a $1 \mathrm{Mb}$ interval identifies long-range ventral forebrain enhancers', Development, 133(4), pp. 761-772. doi: 10.1242/dev.02239.

Jin, Q. et al. (2011) 'Distinct roles of GCN5/PCAF-mediated H3K9ac and CBP/p300-mediated H3K18/27ac in nuclear receptor transactivation', The EMBO Journal, 30(2), pp. 249-262. doi: 10.1038/emboj.2010.318.

Jostes, B., Walther, C. and Gruss, P. (1990) 'The murine paired box gene, Pax7, is expressed specifically during the development of the nervous and muscular system.', Mechanisms of development, 33(1), pp. 27-37. Available at: http://www.ncbi.nlm.nih.gov/pubmed/1982921.

Kaldis, P. and Richardson, H. E. (2012) 'When cell cycle meets development', Development, 139(2), pp. 225-230. doi: 10.1242/dev.073288.

Karlic, R. et al. (2010) 'Histone modification levels are predictive for gene expression', Proceedings of the National Academy of Sciences, 107(7), pp. 2926-2931. doi: 10.1073/pnas.0909344107.

Karmodiya, K. et al. (2012) 'H3K9 and H3K14 acetylation co-occur at many gene regulatory elements, while H3K14ac marks a subset of inactive inducible promoters in mouse embryonic stem cells.', BMC genomics, 13, p. 424. doi: 10.1186/1471-2164-13-424.

Kaye, J. A. et al. (2009) 'A 3'UTR Pumilio-Binding Element Directs Translational Activation in Olfactory Sensory Neurons', Neuron, 61(1), pp. 57-70. doi: 10.1016/j.neuron.2008.11.012.

Kearns, N. A. et al. (2015) 'Functional annotation of native enhancers with a Cas9-histone demethylase fusion', Nature Methods, 12(5), pp. 401-403. doi: 10.1038/nmeth.3325.

Kebede, A. F., Schneider, R. and Daujat, S. (2015) 'Novel types and sites of histone modifications emerge as players in the transcriptional regulation contest', FEBS Journal, 282(9), pp. 1658-1674. doi: 10.1111/febs.13047.

Kennedy, T. E. et al. (1994) 'Netrins are diffusible chemotropic factors for commissural axons in the embryonic spinal cord', Cell, 78(3), pp. 425-435. doi: 10.1016/0092-8674(94)90421-9.

Kim, D. H. et al. (2005) 'Synthetic dsRNA Dicer substrates enhance RNAi potency and efficacy', Nature Biotechnology, 23(2), pp. 222-226. doi: 10.1038/nbt1051.

Kim, D. H. and Rossi, J. J. (2008) 'RNAi mechanisms and applications', BioTechniques, 44(5), pp. 613-616. doi: 10.2144/000112792. 
Kim, V. N. (2005) 'MicroRNA biogenesis: coordinated cropping and dicing', Nature Reviews Molecular Cell Biology, 6(5), pp. 376-385. doi: 10.1038/nrm1644.

Kimura, H. (2013) 'Histone modifications for human epigenome analysis', Journal of Human Genetics, 58(7), pp. 439-445. doi: 10.1038/jhg.2013.66.

Kong, X. et al. (2011) 'Catalytic Mechanism Investigation of Lysine-Specific Demethylase 1 (LSD1): A Computational Study', PLoS ONE. Edited by A. Pastore, 6(9), p. e25444. doi: 10.1371/journal.pone.0025444.

Kouzarides, T. (2007) 'Chromatin Modifications and Their Function', Cell, 128(4), pp. 693-705. doi: 10.1016/j.cell.2007.02.005.

Koyano-Nakagawa, N. and Kintner, C. (2005) 'The expression and function of MTG/ETO family proteins during neurogenesis', Developmental Biology, 278(1), pp. 22-34. doi: 10.1016/j.ydbio.2004.10.010.

Kroll, Kristen, L. (2007) 'Geminin in embryonic development: coordinating transcription and the cell cycle during differentiation', Frontiers in Bioscience, 12(1), p. 1395. doi: 10.2741/2156.

Kunej, T. et al. (2012) 'Cross Talk Between MicroRNA and Coding Cancer Genes', The Cancer Journal, 18(3), pp. 223-231. doi: 10.1097/PPO.0b013e318258b771.

Lacomme, M. et al. (2012) 'NEUROG2 Drives Cell Cycle Exit of Neuronal Precursors by Specifically Repressing a Subset of Cyclins Acting at the G1 and S Phases of the Cell Cycle', Molecular and Cellular Biology, 32(13), pp. 2596-2607. doi: 10.1128/mcb.06745-11.

Lai, H. C., Meredith, D. M. and Johnson, J. E. (2013) 'bHLH Factors in Neurogenesis and Neuronal Subtype Specification', in Patterning and Cell Type Specification in the Developing CNS and PNS. Elsevier, pp. 333-354. doi: 10.1016/B978-0-12-397265-1.00065-4.

Langeland, J. A. et al. (1998) 'An amphioxus snail gene: expression in paraxial mesoderm and neural plate suggests a conserved role in patterning the chordate embryo.', Development genes and evolution, 208(10), pp. 569-77. Available at: http://www.ncbi.nlm.nih.gov/pubmed/9811975.

Larrivee, B. et al. (2007) 'Activation of the UNC5B receptor by Netrin-1 inhibits sprouting angiogenesis', Genes \&amp; Development, 21(19), pp. 2433-2447. doi: 10.1101/gad.437807.

Lawrence, M., Daujat, S. and Schneider, R. (2016) 'Lateral Thinking: How Histone Modifications Regulate Gene Expression', Trends in Genetics, 32(1), pp. 42-56. doi: 10.1016/j.tig.2015.10.007.

Lee, M. G. et al. (2005) 'An essential role for CoREST in nucleosomal histone 3 lysine 4 demethylation', Nature, 437(7057), pp. 432-435. doi: 10.1038/nature04021. 
Lee, M. K. et al. (1990) 'The expression and posttranslational modification of a neuronspecific ?-tubulin isotype during chick embryogenesis', Cell Motility and the Cytoskeleton, 17(2), pp. 118-132. doi: 10.1002/cm.970170207.

Lee, Y. et al. (2004) 'MicroRNA genes are transcribed by RNA polymerase II', The EMBO Journal, 23(20), pp. 4051-4060. doi: 10.1038/sj.emboj.7600385.

Legendre, M. et al. (2006) 'Differential Repression of Alternative Transcripts: A Screen for miRNA Targets', PLoS Computational Biology, 2(5), p. e43. doi: 10.1371/journal.pcbi.0020043.

Lejmi, E. et al. (2008) 'Netrin-4 inhibits angiogenesis via binding to neogenin and recruitment of Unc5B', Proceedings of the National Academy of Sciences, 105(34), pp. 12491-12496. doi: 10.1073/pnas.0804008105.

Levine, M. (2010) 'Transcriptional Enhancers in Animal Development and Evolution', Current Biology, 20(17), pp. R754-R763. doi: 10.1016/j.cub.2010.06.070.

Levine, M., Cattoglio, C. and Tjian, R. (2014) 'Looping back to leap forward: Transcription enters a new era', Cell. Elsevier Inc., 157(1), pp. 13-25. doi: 10.1016/j.cell.2014.02.009.

Lewis, K. E. and Eisen, J. S. (2003) 'From cells to circuits: development of the zebrafish spinal cord.', Progress in neurobiology, 69(6), pp. 419-49. Available at: http://www.ncbi.nlm.nih.gov/pubmed/12880634.

Lin, Y.-C. et al. (2014) 'Genome dynamics of the human embryonic kidney 293 lineage in response to cell biology manipulations', Nature Communications, 5(1), p. 4767. doi: $10.1038 /$ ncomms5767.

Liu, H. et al. (2013) 'Sex determining region Y-box 2 inhibits the proliferation of colorectal adenocarcinoma cells through the mTOR signaling pathway.', International journal of molecular medicine, 32(1), pp. 59-66. doi: 10.3892/ijmm.2013.1354.

Liu, Q. and Hengartnet, M. (1999) 'The Molecular Mechanism of Programmed Cell Death in C. elegans', Annals of the New York Academy of Sciences, 887(1), pp. 92-104. doi: 10.1111/j.1749-6632.1999.tb07925.x.

Liu, Y. et al. (2000) 'qBrain-2, a POU domain gene expressed in quail embryos', Biochimica et Biophysica Acta (BBA) - Gene Structure and Expression, 1491(1-3), pp. 27-36. doi: 10.1016/S0167-4781(00)00011-7.

Livak, K. J. and Schmittgen, T. D. (2001) 'Analysis of Relative Gene Expression Data Using RealTime Quantitative PCR and the 2- $\Delta \Delta C T$ Method', Methods, 25(4), pp. 402-408. doi: 10.1006/meth.2001.1262.

Lopes, M. L., Schmidt, G. S. and Coutinho, L. L. (2000) 'Identification of proliferating cells in 
chicken embryos using 5-bromo- 2'-deoxyuridine immunohistochemical detection', Genetics and Molecular Biology, 23(1), pp. 149-153. doi: 10.1590/S1415-47572000000100028.

Louvi, A. and Artavanis-Tsakonas, S. (2006) 'Notch signalling in vertebrate neural development', Nature Reviews Neuroscience, 7(2), pp. 93-102. doi: 10.1038/nrn1847.

Love, M. I., Huber, W. and Anders, S. (2014) 'Moderated estimation of fold change and dispersion for RNA-seq data with DESeq2', Genome Biology, 15(12), p. 550. doi: 10.1186/s13059-014-0550-8.

Luo, J. et al. (2018) 'SOX2 inhibits cell proliferation and metastasis, promotes apoptotic by downregulating CCND1 and PARP in gastric cancer.', American journal of translational research, 10(2), pp. 639-647. Available at: http://www.ncbi.nlm.nih.gov/pubmed/29511458.

Lutterbach, B. et al. (1998) 'ETO, a Target of $\mathrm{t}(8 ; 21)$ in Acute Leukemia, Interacts with the NCoR and mSin3 Corepressors', Molecular and Cellular Biology, 18(12), pp. 7176-7184. doi: 10.1128/MCB.18.12.7176.

MacFarlane, L.-A. and R. Murphy, P. (2010) 'MicroRNA: Biogenesis, Function and Role in Cancer', Current Genomics, 11(7), pp. 537-561. doi: 10.2174/138920210793175895.

Madarsz, E. (2013) 'Diversity of Neural Stem/Progenitor Populations: Varieties by Age, Regional Origin and Environment', Neural Stem Cells - New Perspectives. doi: 10.5772/55678.

Mandell, J. G. and Barbas, C. F. (2006) 'Zinc Finger Tools: custom DNA-binding domains for transcription factors and nucleases', Nucleic Acids Research, 34(Web Server), pp. W516W523. doi: 10.1093/nar/gkl209.

Manzanares, M., Locascio, A. and Nieto, M. (2001) 'The increasing complexity of the Snail gene superfamily in metazoan evolution', Trends in Genetics, 17(4), pp. 178-181. doi: 10.1016/S0168-9525(01)02232-6.

Margolin, J. F. et al. (1994) 'Kruppel-associated boxes are potent transcriptional repression domains.', Proceedings of the National Academy of Sciences, 91(10), pp. 4509-4513. doi: 10.1073/pnas.91.10.4509.

Marín, F. and Nieto, M. A. (2006) 'The expression of Scratch genes in the developing and adult brain', Developmental Dynamics, 235(9), pp. 2586-2591. doi: 10.1002/dvdy.20869.

Marmorstein, R. and Zhou, M.-M. (2014) 'Writers and Readers of Histone Acetylation: Structure, Mechanism, and Inhibition', Cold Spring Harbor Perspectives in Biology, 6(7), pp. a018762-a018762. doi: 10.1101/cshperspect.a018762.

Matsuda, T. and Cepko, C. L. (2004) 'Electroporation and RNA interference in the rodent retina in vivo and in vitro', Proceedings of the National Academy of Sciences, 101(1), pp. 16-22. 
Mattar, P. et al. (2004) 'A screen for downstream effectors of Neurogenin2 in the embryonic neocortex', Developmental Biology, 273(2), pp. 373-389. doi: 10.1016/j.ydbio.2004.06.013.

Mendenhall, E. M. et al. (2013) 'Locus-specific editing of histone modifications at endogenous enhancers', Nature Biotechnology, 31(12), pp. 1133-1136. doi: 10.1038/nbt.2701.

Metzstein, M. M. and Horvitz, H. R. (1999) 'The C. elegans cell death specification gene ces-1 encodes a snail family zinc finger protein.', Molecular cell, 4(3), pp. 309-19. Available at: http://www.ncbi.nlm.nih.gov/pubmed/10518212.

Mishra, G. R. (2006) 'Human protein reference database--2006 update', Nucleic Acids Research, 34(90001), pp. D411-D414. doi: 10.1093/nar/gkj141.

Misteli, T. et al. (2000) 'Dynamic binding of histone H1 to chromatin in living cells', Nature, 408(6814), pp. 877-881. doi: 10.1038/35048610.

Molina, A. and Pituello, F. (2017) 'Playing with the cell cycle to build the spinal cord', Developmental Biology, 432(1), pp. 14-23. doi: 10.1016/j.ydbio.2016.12.022.

Mullen, R. J., Buck, C. R. and Smith, A. M. (1992) 'NeuN, a neuronal specific nuclear protein in vertebrates.', Development (Cambridge, England), 116(1), pp. 201-11. Available at: http://www.ncbi.nlm.nih.gov/pubmed/1483388.

Murciano, A. et al. (2002) 'Interkinetic Nuclear Movement May Provide Spatial Clues to the Regulation of Neurogenesis', Molecular and Cellular Neuroscience, 21(2), pp. 285-300. doi: 10.1006/mcne.2002.1174.

Nakada Y, Hunsaker TL, H. R. and J. J. (2004) 'Distinct domains within Mash1 and Math1 are required for function in neuronal differentiation versus neuronal cell-type specification', Development, 131(6), pp. 1319-1330. doi: 10.1242/dev.01008.

Nakada, Y. et al. (2004) 'Distinct domains within Mash1 and Math1 are required for function in neuronal differentiation versus neuronal cell-type specification', Development, 131(6), pp. 1319-1330. doi: 10.1242/dev.01008.

Nakakura, E. K. et al. (2001) 'Mammalian Scratch: A neural-specific Snail family transcriptional repressor', Proceedings of the National Academy of Sciences, 98(7), pp. 4010-4015. doi: 10.1073/pnas.051014098.

Nakakura, Eric K. et al. (2001) 'Mammalian Scratch participates in neuronal differentiation in P19 embryonal carcinoma cells', Molecular Brain Research, 95(1-2), pp. 162-166. doi: 10.1016/S0169-328X(01)00246-7.

Naumova, N. et al. (2012) 'Analysis of long-range chromatin interactions using Chromosome Conformation Capture', Methods, 58(3), pp. 192-203. doi: 10.1016/j.ymeth.2012.07.022. 
Nellesen, D. T., Lai, E. C. and Posakony, J. W. (1999) 'Discrete Enhancer Elements Mediate Selective Responsiveness of Enhancer of split Complex Genes to Common Transcriptional Activators', Developmental Biology, 213(1), pp. 33-53. doi: 10.1006/dbio.1999.9324.

Neuwald, A. F. and Landsman, D. (1997) 'GCN5-related histone N-acetyltransferases belong to a diverse superfamily that includes the yeast SPT10 protein.', Trends in biochemical sciences, 22(5), pp. 154-5. Available at: http://www.ncbi.nlm.nih.gov/pubmed/9175471.

Nieto, M. A. (2002) 'The snail superfamily of zinc-finger transcription factors', Nature Reviews Molecular Cell Biology, 3(3), pp. 155-166. doi: 10.1038/nrm757.

Oleksiewicz, U. et al. (2017) 'TRIM28 and Interacting KRAB-ZNFs Control Self-Renewal of Human Pluripotent Stem Cells through Epigenetic Repression of Pro-differentiation Genes', Stem Cell Reports, 9(6), pp. 2065-2080. doi: 10.1016/j.stemcr.2017.10.031.

Ong, C.-T. and Corces, V. G. (2011) 'Enhancer function: new insights into the regulation of tissue-specific gene expression', Nature Reviews Genetics, 12(4), pp. 283-293. doi: $10.1038 / \mathrm{nrg} 2957$.

Parras, C. M. et al. (2002) 'Divergent functions of the proneural genes Mash1 and Ngn2 in the specification of neuronal subtype identity', Genes and Development, 16(3), pp. 324-338. doi: 10.1101/gad.940902.

Patel, A. et al. (2009) 'On the Mechanism of Multiple Lysine Methylation by the Human Mixed Lineage Leukemia Protein-1 (MLL1) Core Complex', Journal of Biological Chemistry, 284(36), pp. 24242-24256. doi: 10.1074/jbc.M109.014498.

Paul, V. et al. (2012) 'Scratch2 modulates neurogenesis and cell migration through antagonism of bHLH proteins in the developing neocortex', Cerebral Cortex, 24(3), pp. 754-772. doi: $10.1093 /$ cercor/bhs356.

Perez, S. E., Rebelo, S. and Anderson, D. J. (1999) 'Early specification of sensory neuron fate revealed by expression and function of neurogenins in the chick embryo.', Development (Cambridge, England), 126(8), pp. 1715-28. Available at: http://www.ncbi.nlm.nih.gov/pubmed/10079233.

Perrone-Bizzozero, N. and Bolognani, F. (2002) 'Role of HuD and other RNA-binding proteins in neural development and plasticity', Journal of Neuroscience Research, 68(2), pp. 121-126. doi: $10.1002 /$ jnr.10175.

Perry, M. W., Boettiger, A. N. and Levine, M. (2011) 'Multiple enhancers ensure precision of gap gene-expression patterns in the Drosophila embryo', Proceedings of the National Academy of Sciences, 108(33), pp. 13570-13575. doi: 10.1073/pnas.1109873108.

Perry, R. B.-T. and Ulitsky, I. (2016) 'The functions of long noncoding RNAs in development and 
stem cells', Development, 143(21), pp. 3882-3894. doi: 10.1242/dev.140962.

Phan, K. D. et al. (2011) 'Neogenin May Functionally Substitute for Dcc in Chicken', PLoS ONE. Edited by I. Sugihara, 6(7), p. e22072. doi: 10.1371/journal.pone.0022072.

Place, R. F. et al. (2008) 'MicroRNA-373 induces expression of genes with complementary promoter sequences', Proceedings of the National Academy of Sciences, 105(5), pp. 16081613. doi: $10.1073 /$ pnas.0707594105.

Rada-Iglesias, A. et al. (2011) 'A unique chromatin signature uncovers early developmental enhancers in humans.', Nature, 470(7333), pp. 279-83. doi: 10.1038/nature09692.

Raisner, R. et al. (2018) 'Enhancer Activity Requires CBP/P300 Bromodomain-Dependent Histone H3K27 Acetylation', Cell Reports, 24(7), pp. 1722-1729. doi: 10.1016/j.celrep.2018.07.041.

Rajagopalan, S. et al. (2004) 'Neogenin mediates the action of repulsive guidance molecule', Nature Cell Biology, 6(8), pp. 756-762. doi: 10.1038/ncb1156.

Ramat, A. et al. (2016) 'Escargot and Scratch regulate neural commitment by antagonizing Notch activity in Drosophila sensory organs', Development, 143(16), pp. 3024-3034. doi: 10.1242/dev.134387.

Rand, M. D., Lake, R. J. and Artavanis-Tsakonas, S. (1999) 'Notch Signaling: Cell Fate Control and Signal Integration in Development', Science, 284(5415), pp. 770-776. doi: 10.1126/science.284.5415.770.

Raposo, A. A. S. F. et al. (2015) 'Ascl1 coordinately regulates gene expression and the chromatin landscape during neurogenesis', Cell Reports, 10(9), pp. 1544-1556. doi: 10.1016/j.celrep.2015.02.025.

Rathjen, T. et al. (2009) 'High throughput sequencing of microRNAs in chicken somites', FEBS Letters. Federation of European Biochemical Societies, 583(9), pp. 1422-1426. doi: 10.1016/j.febslet.2009.03.048.

Richman, R. et al. (1988) 'Micronuclei and the cytoplasm of growing Tetrahymena contain a histone acetylase activity which is highly specific for free histone $\mathrm{H} 4$ ', The Journal of Cell Biology, 106(4), pp. 1017-1026. doi: 10.1083/jcb.106.4.1017.

Roark, M. et al. (1995) 'Scratch, a Pan-Neural Gene Encoding a Zinc Finger Protein Related To Snail, Promotes Neuronal Development', Genes and Development, 9(19), pp. 2384-2398. doi: 10.1101/gad.9.19.2384.

Robertshaw, E. et al. (2013) 'Irx3 and Pax6 establish differential competence for Shh-mediated induction of GABAergic and glutamatergic neurons of the thalamus', Proceedings of the 
National Academy of Sciences, 110(41), pp. E3919-E3926. doi: 10.1073/pnas.1304311110.

Rodríguez-Aznar, E., Barrallo-Gimeno, A. and Nieto, M. A. (2013) 'Scratch2 prevents cell cycle re-entry by repressing miR-25 in postmitotic primary neurons', Annals of Internal Medicine, 158(6), pp. 5095-5105. doi: 10.1523/JNEUROSCI.4459-12.2013.

Rodríguez-Aznar, E. and Nieto, M. A. (2011) 'Repression of Puma by Scratch2 is required for neuronal survival during embryonic development', Cell Death and Differentiation, 18(7), pp. 1196-1207. doi: 10.1038/cdd.2010.190.

Roeder, R. G. (1996) '[14] Nuclear RNA polymerases: Role of general initiation factors and cofactors in eukaryotic transcription', in, pp. 165-171. doi: 10.1016/S0076-6879(96)73016-1.

Rogers, C. D. et al. (2009) 'Xenopus Sox3 activates sox2 and geminin and indirectly represses Xvent2 expression to induce neural progenitor formation at the expense of non-neural ectodermal derivatives', Mechanisms of Development, 126(1-2), pp. 42-55. doi: 10.1016/j.mod.2008.10.005.

Rothbart, S. B. and Strahl, B. D. (2014) 'Interpreting the language of histone and DNA modifications', Biochimica et Biophysica Acta - Gene Regulatory Mechanisms, 1839(8), pp. 627-643. doi: 10.1016/j.bbagrm.2014.03.001.

Rothe, M. et al. (2016) 'Comparative expression study of sipa family members during early Xenopus laevis development', Development Genes and Evolution, 226(5), pp. 369-382. doi: 10.1007/s00427-016-0556-1.

Sakurai, K. and Osumi, N. (2008) 'The Neurogenesis-Controlling Factor, Pax6, Inhibits Proliferation and Promotes Maturation in Murine Astrocytes', Journal of Neuroscience, 28(18), pp. 4604-4612. doi: 10.1523/jneurosci.5074-07.2008.

Sander, M. et al. (2000) 'Ventral neural patterning by Nkx homeobox genes: Nkx6.1 controls somatic motor neuron and ventral interneuron fates.', Genes \& development, 14(17), pp. 2134-9. doi: 10.1101/gad.820400.

Sandmann, T. et al. (2006) 'A Temporal Map of Transcription Factor Activity: Mef2 Directly Regulates Target Genes at All Stages of Muscle Development', Developmental Cell, 10(6), pp. 797-807. doi: 10.1016/j.devcel.2006.04.009.

Sasai, Y. et al. (1994) 'Xenopus chordin: A novel dorsalizing factor activated by organizerspecific homeobox genes', Cell, 79(5), pp. 779-790. doi: 10.1016/0092-8674(94)90068-X.

Sayed, D. and Abdellatif, M. (2011) 'MicroRNAs in Development and Disease', Physiological Reviews, 91(3), pp. 827-887. doi: 10.1152/physrev.00006.2010.

Scardigli, R. et al. (2001) 'Crossregulation between Neurogenin2 and pathways specifying 
neuronal identity in the spinal cord', Neuron, 31(2), pp. 203-217. doi: 10.1016/S08966273(01)00358-0.

Schultz, D. et al. (2002) 'SETDB1: a novel KAP-1-associated histone H3, lysine 9-specific methyltransferase that contributes to HP1-mediated silencing of euchromatic genes by KRAB zinc-finger proteins', Genes \& Development, 16(8), pp. 919-932. doi: 10.1101/gad.973302.

Shi, Yujiang et al. (2004) 'Histone Demethylation Mediated by the Nuclear Amine Oxidase Homolog LSD1', Cell, 119(7), pp. 941-953. doi: 10.1016/j.cell.2004.12.012.

Shibata, M. et al. (2011) 'MicroRNA-9 Regulates Neurogenesis in Mouse Telencephalon by Targeting Multiple Transcription Factors', Journal of Neuroscience, 31(9), pp. 3407-3422. doi: 10.1523/JNEUROSCI.5085-10.2011.

Shimojo, H., Ohtsuka, T. and Kageyama, R. (2011) 'Dynamic expression of Notch signaling genes in neural stem/ progenitor cells', Frontiers in Neuroscience, 5(JUN), pp. 1-7. doi: 10.3389/fnins.2011.00078.

Shin, H. Y. et al. (2017) 'CRISPR/Cas9 targeting events cause complex deletions and insertions at 17 sites in the mouse genome', Nature Communications. Nature Publishing Group, 8(May), pp. 1-10. doi: 10.1038/ncomms15464.

Shin, J.-O. et al. (2012) 'miR-200b regulates cell migration via Zeb family during mouse palate development', Histochemistry and Cell Biology, 137(4), pp. 459-470. doi: 10.1007/s00418012-0915-6.

Shlyueva, D., Stampfel, G. and Stark, A. (2014) 'Transcriptional enhancers: From properties to genome-wide predictions', Nature Reviews Genetics. Nature Publishing Group, 15(4), pp. 272286. doi: $10.1038 / \mathrm{nrg} 3682$.

Siemen, H. et al. (2011) 'Pumilio-2 Function in the Mouse Nervous System', PLoS ONE. Edited by X. Zhuang, 6(10), p. e25932. doi: 10.1371/journal.pone.0025932.

Simmons, A. D. et al. (2001) 'Neurogenin2 expression in ventral and dorsal spinal neural tube progenitor cells is regulated by distinct enhancers', Developmental Biology, 229(2), pp. 327339. doi: $10.1006 /$ dbio.2000.9984.

Skene, P. J., Henikoff, J. G. and Henikoff, S. (2018) 'Targeted in situ genome-wide profiling with high efficiency for low cell numbers', Nature Protocols. Nature Publishing Group, 13(5), pp. 1006-1019. doi: 10.1038/nprot.2018.015.

Small, S., Blair, A. and Levine, M. (1992) 'Regulation of even-skipped stripe 2 in the Drosophila embryo.', The EMBO journal, 11(11), pp. 4047-57. Available at: http://www.ncbi.nlm.nih.gov/pubmed/1327756. 
Smith, J. and Schoenwolf, G. (1997) 'Neurulation: coming to closure', Trends in Neurosciences, 20(11), pp. 510-517. doi: 10.1016/S0166-2236(97)01121-1.

Soufi, A., Donahue, G. and Zaret, K. S. (2012) 'Facilitators and impediments of the pluripotency reprogramming factors' initial engagement with the genome.', Cell, 151(5), pp. 994-1004. doi: 10.1016/j.cell.2012.09.045.

Spilker, C. et al. (2008) 'SPAR2, a novel SPAR-related protein with GAP activity for Rap1 and Rap2', Journal of Neurochemistry, pp. 071027034046003-??? doi: 10.1111/j.14714159.2007.04991.x.

Spitz, F. and Furlong, E. E. M. (2012) 'Transcription factors: From enhancer binding to developmental control', Nature Reviews Genetics. Nature Publishing Group, 13(9), pp. 613626. doi: $10.1038 / \mathrm{nrg} 3207$.

Splinter, E., Grosveld, F. and Laat, W. de (2003) '3C Technology: Analyzing the Spatial Organization of Genomic Loci In Vivo', in, pp. 493-507. doi: 10.1016/S0076-6879(03)75030-7.

Sripathy, S. P., Stevens, J. and Schultz, D. C. (2006) 'The KAP1 Corepressor Functions To Coordinate the Assembly of De Novo HP1-Demarcated Microenvironments of Heterochromatin Required for KRAB Zinc Finger Protein-Mediated Transcriptional Repression', Molecular and Cellular Biology, 26(22), pp. 8623-8638. doi: 10.1128/MCB.0048706.

Stanojevic, D., Small, S. and Levine, M. (1991) 'Regulation of a segmentation stripe by overlapping activators and repressors in the Drosophila embryo', Science, 254(5036), pp. 1385-1387. doi: 10.1126/science.1683715.

Stephens, M. (2016) 'False discovery rates: a new deal', Biostatistics, p. kxw041. doi: 10.1093/biostatistics/kxw041.

Stormo, G. D. and Zhao, Y. (2010) 'Determining the specificity of protein-DNA interactions', Nature Reviews Genetics. Nature Publishing Group, 11(11), pp. 751-760. doi: $10.1038 / \mathrm{nrg} 2845$.

Strahl, B. D. and Allis, C. D. (2000) 'The language of covalent histone modifications', Nature, 403(6765), pp. 41-45. doi: 10.1038/47412.

Sugitani, Y. (2002) 'Brn-1 and Brn-2 share crucial roles in the production and positioning of mouse neocortical neurons', Genes \& Development, 16(14), pp. 1760-1765. doi: 10.1101/gad.978002.

Sun, M. and Kraus, W. L. (2015) 'From Discovery to Function: The Expanding Roles of Long NonCoding RNAs in Physiology and Disease', Endocrine Reviews, 36(1), pp. 25-64. doi: 10.1210/er.2014-1034. 
Sunabori, T. et al. (2008) 'Cell-cycle-specific nestin expression coordinates with morphological changes in embryonic cortical neural progenitors', Journal of Cell Science, 121(8), pp. 12041212. doi: $10.1242 /$ jcs.025064.

Swartz, M. E. et al. (2001) 'EphA4/ephrin-A5 interactions in muscle precursor cell migration in the avian forelimb.', Development (Cambridge, England), 128(23), pp. 4669-80. Available at: http://www.ncbi.nlm.nih.gov/pubmed/11731448.

Szyf, M. (2015) 'Nongenetic inheritance and transgenerational epigenetics', Trends in Molecular Medicine. Elsevier Ltd, 21(2), pp. 134-144. doi: 10.1016/j.molmed.2014.12.004.

Takahashi, K. and Yamanaka, S. (2006) 'Induction of Pluripotent Stem Cells from Mouse Embryonic and Adult Fibroblast Cultures by Defined Factors', Cell, 126(4), pp. 663-676. doi: 10.1016/j.cell.2006.07.024.

Tanaka, S. et al. (2004) 'Interplay of SOX and POU Factors in Regulation of the', Microbiology, 24(20), pp. 8834-8846. doi: 10.1128/MCB.24.20.8834.

Thellmann, M., Hatzold, J. and Conradt, B. (2003) 'The Snail-like CES-1 protein of C. elegans can block the expression of theBH3-only cell-death activator gene egl-1 by antagonizing the function of bHLH proteins', Development, 130(17), pp. 4057-4071. doi: 10.1242/dev.00597.

Thibodeau, A. et al. (2017) 'Chromatin interaction networks revealed unique connectivity patterns of broad H3K4me3 domains and super enhancers in 3D chromatin', Scientific Reports, 7(1), p. 14466. doi: 10.1038/s41598-017-14389-7.

Torchia, J., Glass, C. and Rosenfeld, M. G. (1998) 'Co-activators and co-repressors in the integration of transcriptional responses.', Current opinion in cell biology, 10(3), pp. 373-83. Available at: http://www.ncbi.nlm.nih.gov/pubmed/9640539.

Trizzino, M., Kapusta, A. and Brown, C. D. (2018) 'Transposable elements generate regulatory novelty in a tissue-specific fashion', BMC Genomics, 19(1), p. 468. doi: 10.1186/s12864-0184850-3.

Turner, E. C. et al. (2004) 'Controlling the DNA Binding Specificity of bHLH Proteins through Intramolecular Interactions', Chemistry \& Biology, 11(1), pp. 69-77. doi: 10.1016/j.chembiol.2003.12.015.

Uchikawa, M. et al. (2003) 'Functional Analysis of Chicken Sox2 Enhancers Highlights an Array of Diverse Regulatory Elements that Are Conserved in Mammals activated Sox2 (Figure 1A, st. 5-8). At neurulation stages when the sheet of Sox2-expressing cells converges (Fig-ure $1 \mathrm{~A}$, st. 8)', Developmental Cell, 4, pp. 509-519.

Ulitsky, I. et al. (2011) 'Conserved Function of lincRNAs in Vertebrate Embryonic Development despite Rapid Sequence Evolution', Cell, 147(7), pp. 1537-1550. doi: 
10.1016/j.cell.2011.11.055.

Urrutia, R. (2003) 'Protein family review KRAB-containing zinc-finger repressor proteins', Genome Biology, 4, p. 231. Available at: http://genomebiology.com/2003/4/10/231.

Valencia-Sanchez, M. A. et al. (2006) 'Control of translation and mRNA degradation by miRNAs and siRNAs', Genes and Development, 20(5), pp. 515-524. doi: 10.1101/gad.1399806.

Vieceli, F. M. et al. (2013) 'The transcription factor chicken Scratch2 is expressed in a subset of early postmitotic neural progenitors', Gene Expression Patterns. Elsevier B.V., 13(5-6), pp. 189-196. doi: 10.1016/j.gep.2013.03.004.

Waddington, C. H. (1942) 'The Epigenotype', Endeavour, pp. 18-20. doi: 10.1093/ije/dyr184.

Wallace, K., Liu, T. H. and Vaessin, H. (2000) 'The pan-neural bHLH proteins DEADPAN and ASENSE regulate mitotic activity and cdk inhibitor dacapo expression in the Drosophila larval optic lobes.', Genesis (New York, N.Y. : 2000), 26(1), pp. 77-85.

Wang, H. N. et al. (2012) 'Identification and characterization of the pumilio-2 expressed in zebrafish embryos and adult tissues', Molecular Biology Reports, 39(3), pp. 2811-2819. doi: 10.1007/s11033-011-1040-7.

Wapinski, O. L. et al. (2013) 'Hierarchical Mechanisms for Direct Reprogramming of Fibroblasts to Neurons', Cell, 155(3), pp. 621-635. doi: 10.1016/j.cell.2013.09.028.

Wei, H. et al. (2017) 'Caenorhabditis elegans CES-1 Snail Represses pig-1 MELK Expression To Control Asymmetric Cell Division', Genetics, 206(4), pp. 2069-2084. doi: 10.1534/genetics.117.202754.

Whyte, W. A. et al. (2012) 'Enhancer decommissioning by LSD1 during embryonic stem cell differentiation', Nature, 482(7384), pp. 221-225. doi: 10.1038/nature10805.

Wianny, F. and Zernicka-Goetz, M. (2000) 'Specific interference with gene function by doublestranded RNA in early mouse development', Nature Cell Biology, 2(2), pp. 70-75. doi: $10.1038 / 35000016$.

Williams, R. M. et al. (2018) 'Genome and epigenome engineering CRISPR toolkit for in vivo modulation of cis -regulatory interactions and gene expression in the chicken embryo', Development, 145(4), p. dev160333. doi: 10.1242/dev.160333.

Wilson, B. et al. (2006) 'Netrins Promote Developmental and Therapeutic Angiogenesis', Science, 313(5787), pp. 640-644. doi: 10.1126/science.1124704.

Wilson, N. H. and Key, B. (2007) 'Neogenin: One receptor, many functions', The International Journal of Biochemistry \& Cell Biology, 39(5), pp. 874-878. doi: 10.1016/j.biocel.2006.10.023. 
Wolf, G., Greenberg, D. and Macfarlan, T. S. (2015) 'Spotting the enemy within: Targeted silencing of foreign DNA in mammalian genomes by the Krüppel-associated box zinc finger protein family', Mobile DNA, 6(1), p. 17. doi: 10.1186/s13100-015-0050-8.

Wysocka, J. and Herr, W. (2003) 'The herpes simplex virus VP16-induced complex: the makings of a regulatory switch', Trends in Biochemical Sciences, 28(6), pp. 294-304. doi: 10.1016/S0968-0004(03)00088-4.

Yan, B. et al. (2013) 'Coordination of cell proliferation and cell fate determination by CES-1 snail.', PLoS genetics, 9(10), p. e1003884. doi: 10.1371/journal.pgen.1003884.

Yao, C.-X. et al. (2013) 'miR-200b targets GATA-4 during cell growth and differentiation', RNA Biology, 10(4), pp. 465-480. doi: 10.4161/rna.24370.

Ye, B. et al. (2004) 'nanos and pumilio Are Essential for Dendrite Morphogenesis in Drosophila Peripheral Neurons', Current Biology, 14(4), pp. 314-321. doi: 10.1016/j.cub.2004.01.052.

Yu, D. et al. (2012) 'Single-stranded RNAs use RNAi to potently and allele-selectively inhibit mutant huntingtin expression', Cell, 150(5), pp. 895-908. doi: 10.1016/j.cell.2012.08.002.

Zampetaki, A., Albrecht, A. and Steinhofel, K. (2018) 'Long Non-coding RNA Structure and Function: Is There a Link?', Frontiers in Physiology, 9. doi: 10.3389/fphys.2018.01201.

Zaret, K. S. and Carroll, J. S. (2011) 'Pioneer transcription factors: establishing competence for gene expression', Genes \& Development, 25(21), pp. 2227-2241. doi: 10.1101/gad.176826.111.

Zentner, G. E., Tesar, P. J. and Scacheri, P. C. (2011) 'Epigenetic signatures distinguish multiple classes of enhancers with distinct cellular functions', Genome Research, 21(8), pp. 1273-1283. doi: 10.1101/gr.122382.111.

Zhao, W. et al. (2017) 'CRISPR-Cas9-mediated functional dissection of 3'-UTRs', Nucleic Acids Research, 45(18), pp. 10800-10810. doi: 10.1093/nar/gkx675.

Zhao, X. et al. (2010) 'MicroRNA-Mediated Control of Oligodendrocyte Differentiation', Neuron. Elsevier Ltd, 65(5), pp. 612-626. doi: 10.1016/j.neuron.2010.02.018. 